\title{
What Determines the Decision to Implement EMAS? A European Firm Level Study
}

\author{
Roeland Bracke · Tom Verbeke • Veerle Dejonckheere
}

Accepted: 7 March 2008 / Published online: 23 March 2008

(C) Springer Science+Business Media B.V. 2008

\begin{abstract}
Empirical research on the characteristics of environmentally responsive companies has focussed on US and Japanese companies. For Europe, which is commonly considered as the greenest of the three major markets, similar research is lacking. This paper seeks to fill this gap by empirically investigating business and financial characteristics, stakeholder pressures and public policies to distinguish companies that have implemented the European Eco-Management and Audit System (EMAS) from a unique firm-level dataset of European publicly quoted companies. We find that the EMAS participation decision is positively influenced by the solvency ratio, the share of non-current liabilities, the average labour cost and the absolute company size as well as the relative size of a company compared to its sector average. The profit margin exerts a negative influence. We further find that companies whose headquarters is located in a country that actively encourages EMAS have a higher probability of participation. Finally, this paper suggests that rather than attracting other kinds of companies, a favourable institutional context succeeds in convincing more of the same kind of companies to participate.
\end{abstract}

The authors thank anonymous referees for providing helpful comments and suggestions on earlier drafts of this paper.

R. Bracke $(\square)$

Centre for Environmental Economics and Management, Faculty of Economics and Business Administration, Ghent University, Tweekerkenstraat 2, 9000 Ghent, Belgium

e-mail: roeland.bracke@ugent.be

T. Verbeke

Centre for Corporate Sustainability (CEDON), European University College, Stormstraat 2, 1000

Brussels, Belgium

e-mail: Tom.verbeke@ehsal.be

V. Dejonckheere

Laboratory of Food Technology and Engineering, Ghent University, Coupure Links 653, 9000 Ghent, Belgium

e-mail: Veerle.dejonckheere@ugent.be 
Keywords Business and financial characteristics - EMAS participation - Logistic regression · Stakeholder pressures

\section{Introduction}

In response to increasing stakeholder pressure, companies are embracing the "corporate social responsibility" concept evermore tightly. Social, environmental and sustainability reports are being published at an accelerating pace. Participation in voluntary environmental approaches is a straightforward manner to show a corporation's involvement. Within the wide scope of voluntary approaches, public voluntary programmes have an attractive appeal. In such programmes participating firms agree to standards that have been developed by public bodies such as environmental agencies (OECD 1999). Well-known examples include environmental management systems (EMS) like the worldwide ISO 14001 standard and the European EcoManagement and Audit Scheme (EMAS), programmes developed by the US Environmental Protection Agency (EPA) such as Energy Star, Green Lights, and 33/50 and numerous environmental or social product labels. The appealing character lies in the fact that the credibility of these programmes is guaranteed by the initiators' public function and/or the external validation of a company's compliance with the programme. As most programmes allow the use of a logo, they are attractive instruments for companies to signal their proactive stance to various stakeholders. Furthermore, some programmes provide participants with regulatory relief, subsidies or information sharing initiatives.

Not surprisingly, participation rates are booming. The number of ISO 14001 certified companies has risen from 14,106 in December 1999 to 111,162 in five years time (ISO 2006). Participation in EMAS has tripled to 3,389 organisations between 1997 and 2006. ${ }^{1}$ A growth of $127 \%$ of the number of fairtrade certified producers has been experienced between 2001 and 2005 (Fairtrade Labelling Organizations International 2006).

The question that emerges, "what causes some companies to pursue a pro-active strategy by participating in these programs whereas other companies seem to prefer a defensive strategy?" has received considerable attention in the literature. A wide range of internal characteristics (e.g. capital intensity, size, profitability and financial structure) as well as external drivers (e.g. pressure from regulators, consumers, investors and local community) has been examined. As a literature survey of Alberini and Segerson (2002) however points out, the evidence on many determinants is not conclusive. Our research seeks to contribute to this line of research in two ways: the focus on EMAS and the European scope of the sample.

First, we analyse company participation in EMAS. Related research focused on ISO 14001 (Nakamura et al. 2001; Hibiki et al. 2003; Potoski and Prakash 2005) or on the comprehensiveness of environmental management practices implemented within firms (Dasgupta et al. 2000; Khanna and Anton 2002; Anton et al. 2004; Cole et al. 2006). Other papers focussed on the participation decision towards several US EPA's voluntary programmes such as the 33/50 program (Arora and Cason 1995, 1996; Khanna and Damon 1999; Videras and Alberini 2000), Green Lights (DeCanio and Watkins 1998; Videras and Alberini 2000) and Waste Wi\$e (Videras and Alberini 2000). King and Lenox (2000) studied companies' participation decision in the Chemical Industry's Responsible Care Program. Finally, Henriques and Sadorsky (1996) examined the motivations explaining firms' formulation of an environmental plan.

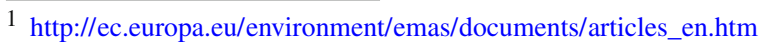


The focus on EMAS is relevant in two regards. First, EMAS is a program developed by the European Commission (Council Regulation No 1836/93 of June 1993 and replaced in March 2001 by Regulation No 761/2001) and is administered by the Union's Member States. Compared to other voluntary approaches like ISO 14001 or Responsible Care, which are private sector initiatives, EMAS is a public regulation to which companies can voluntary subscribe. As such, it can be situated at the junction between voluntary initiatives and public regulations. As a result one might expect that other determinants become relevant for explaining the uptake compared to private initiatives like ISO 14001. Benefits might rather relate to aspects like stakeholder communication, regulatory flexibility or gaining regulator's trust whereas ISO 14001 might rather be rewarded in the market place. As such, financial and business characteristics might become less influential here. Second, as EMAS is perceived as being more demanding than ISO 14001, it may present a better picture of environmental responsiveness. In addition to the general requirements of installing an ISO 14001-like EMS, EMAS places special attention to the following elements: legal compliance, improvement of environmental performance, external communication and employee involvement. EMAS is considered as the standard of environmental excellence and is more stringent and demanding than ISO 14001 (e.g. Kollman and Prakash 2002; Watson and Emery 2004). As a result, it can be expected that implementing EMAS is more costly than ISO 14001. Consequently, the number of EMAS registered companies is rather small compared to the number of ISO 14001 certified ones. In December 2005, ISO 14001 outnumbered EMAS by a factor 10 in the EU-15. As such, it can be argued that the decision to participate in EMAS is taken more thoughtfully.

The second distinguishing feature is the European sample. This is the first study on the characteristics of green companies that uses a European firm-level dataset. Previous research has focused principally on US companies for the EPA's voluntary programmes (see above for references). Studies on ISO 14001 are mainly based on a sample of Japanese companies (see above for references). Henriques and Sadorsky (1996) took a sample of Canadian companies and Mexican companies were the subjects of the study of Dasgupta et al. (2000).

The focus on European companies might deliver new insights as the institutional context is different from that in the US or Japan. Japan is known to possess highly corporatist business structures, and the local regulators have an important role in environmental policy making that is based on legal informality and business responsibility (Welch and Hibiki 2002). The US on the other hand is characterised by an individualistic ethos and free capitalism (Vogel 1986). The environmental policy is legalistic and centralised resulting in adversarial privatepublic relationships (Delmas and Terlaak 2002). Europe takes a position somewhere in the middle. Environmental policy is rather characterised as cooperative with consensus-based consultations entailing many access points for public organisations. Especially for voluntary approaches, which are said to produce mainly soft benefits (OECD 1999), these differences could be of some importance. Again one might conclude that sheer financial and business drivers will be less important for explaining EMAS uptake.

Within the wide range of potential determinants for environmentally responsive behaviour, this paper focuses on business and financial indicators, stakeholder pressures and public policy. The results indicate that a company's financial structure, profitability, size and average labour cost are significant drivers of EMAS registration. We also find that the type of a firm's activities and the location of its headquarters influence the likelihood of participation.

The paper is structured in the following sections. Section 2 presents the data and the model. The hypotheses and variables are discussed in Sect. 3. Section 4 presents the estimation results and Sect. 5 concludes. 


\section{Data and Methodology}

This paper merges two firm-level datasets that, as far as we are aware, have not previously been combined. The first, the Amadeus database (Bureau van Dijk Electronic Publishing, update 131, August 2005), provides company-level data. Amadeus (Analyse Major Databases from European Sources) is a comprehensive, pan-European database containing financial information on approximately 8 million private and public companies in 38 European Countries.

The second consists of the list of EMAS registered organisations (received from the EMAS helpdesk on the 25th of October, 2005). Both databases were linked using a companies ISIN (International Securities Identification Number) number. The ISIN number is a code that uniquely identifies a specific security and is accepted as standard by virtually all countries. EMAS is an environmental management standard that seeks to assist firms in evaluating, reporting and improving their environmental performance (Honkasalo 1998). In short, a company seeking EMAS registration must comply with the following steps: (1) conduct an environmental review; (2) establish an environmental management system; (3) carry out an environmental audit and (4) publish an environmental statement on the company's environmental performance. ${ }^{2}$ Each step has to be approved by an accredited verifier. As such, EMAS requires companies to evaluate their environmental impacts and to set targets for improvement on a continuous basis. The cost of implementing EMAS might be considerable. Steger (2000), for example, reports that the costs of acquiring the standard generally lie in the range $€ 50,000-100,000$. Clausen et al. (2002) report figures for companies with over 500 employees. The estimates range from $€ 85.000$ up to $€ 322.000$. Furthermore, a firm also incurs costs for maintaining the environmental management system and follow-up audits.

Our sample consists of the companies listed in the Dow Jones STOXX 600 Monthly Selection list of November $2005 .^{3}$ This list registers the largest publicly quoted companies from the EU-15, Norway and Switzerland. In November 2005 there were 968 companies on this list 74 of which were marked as EMAS registered. ${ }^{4}$ From this list, we excluded a number of companies. ${ }^{5}$ First, we eliminated holding companies (Nace Revision 1.1 codes 7414 and 7415) because we believe their idiosyncratic characteristics might distort the results. Second, due to data limitations, we did not include companies not covered in Amadeus (especially banks and insurance companies) or companies with missing values on some items. Third, companies with less then 500 employees were eliminated. ${ }^{6}$ This resulted in a final sample of 436 observations of which $38(8.7 \%)$ are EMAS participants. The number of participants in the total sample $(8.7 \%)$ is low, but in line with some similar research (e.g. Arora and Cason 1996; King and Lenox 2000; Potoski and Prakash 2005). The sample consists of large and publicly quoted companies. Due to their visibility it is quite plausible to assume that all of them face at least some public scrutiny, receive a lot of cover in the financial press and face financial analysts who track and evaluate their performance on a daily basis. Probably most of these companies have several environmental and/or social projects running, publish sustainability reports and have, to some extent, implemented environmental management practices. Presumably a rather high percentage is ISO 14001 certified. It should be noted that whereas

\footnotetext{
${ }^{2}$ Further information can be found at http://ec.europa.eu/environment/emas/index_en.htm

3 Available at www.stoxx.com/info/reports/selection2005.html

4 The EMAS helpdesk lists all organisations at facility level. Our sample however consists of companies at group level. As such, following Nakamura et al. (2001) and Hibiki et al. (2003), an organisation was marked as an EMAS participant if at least one of its facilities was registered.

5 The results presented in this paper do not substantially differ from the results without the sample restrictions. These results are available from the authors.

6 This was done due to our doubts on the accuracy of these data. 53 companies were lost.
} 
ISO 14001 and EMAS could, in theory, be considered as substitutes, this is often not the case in practice. Although, in contrast to EMAS, data on ISO 14001 certified companies in the European Union is not available, is safe to assume that a considerable number of companies have implemented both standards. ${ }^{7}$ In June 1998, close to half of the companies that were EMAS-registered also held an ISO 14001 certificate, while another third intended to go for ISO 14001 certification (Hillary 1998). Moreover, with the revision of the EMAS regulation of 2001, ISO 14001 is considered as fulfilling the management system element of EMAS. This was done with the explicit aim to induce ISO 14001 certified companies to take an additional effort to become EMAS. As such, our analysis might reveal the characteristics identifying those companies that have taken the extra step.

As EMAS is a voluntary scheme, companies' participation decision will follow from a comparison of the monetary and non-monetary costs and benefits. The cost estimates referred to above, indicate that adopting EMAS imposes nontrivial costs. Moreover, costs are not limited to the implementation process. EMAS is likely to continuously impose costs as it requires greater coordination of activities within the company and imposes costs of employee training, environmental auditing and product and process improvements (Khanna and Anton 2002). Potoski and Prakash (2005) consider certified EMSs as club goods. In return for the costs, participants receive private benefits, i.e. non-participants are excuded from these benefits. Benefits might include increased operational efficiency, regulatory relief, technical information, and easier access to funds or less tangible rewards such as goodwill from consumers, environmental organisations and regulators. As Dasgupta et al. (2000) point out, regulatory initiatives to encourage EMS adoption might be a policy option worth considering. They argue that EMSs bring down companies' marginal abatement costs. If the downward shift of the marginal abatement curve is sufficiently strong, it might result in a lower level of emissions compared to an increase in the control and enforcement budget. Due to heterogeneity of company characteristics, the costs and benefits associated with EMAS adoption are likely to vary across companies (Khanna and Anton 2002). This explains why some companies have adopted EMAS and why others choose not to.

Assume that both discounted monetary and non-monetary costs (C) and benefits (B) are influenced by the business characteristics (b) of the firm, the financial characteristics (f) as well as stakeholder pressure and public policy (s), i.e. $\mathrm{C}=\mathrm{C}(\mathrm{b}, \mathrm{f}, \mathrm{s})$ and $\mathrm{B}=\mathrm{B}(\mathrm{b}, \mathrm{f}, \mathrm{s})$. One would expect that a firm would implement EMAS if the profits $(\mathrm{P})$ from doing so are positive, i.e. if $\mathrm{P}(\mathrm{b}, \mathrm{f}, \mathrm{s})=\mathrm{B}(\mathrm{b}, \mathrm{f}, \mathrm{s})-\mathrm{C}(\mathrm{b}, \mathrm{f}, \mathrm{s})>0$. However, a company's net benefit from EMAS implementation is not directly observed. We only observe the participation decision. However, if we assume that for all EMAS registered companies discounted benefits outweigh discounted costs whereas for all non-registered companies profits from EMAS implementation are negative, we can create a binary choice variable (D(EMAS)) as

$$
D(E M A S)_{i}= \begin{cases}1 & \text { if } P_{i}(b, f, s)>0 \\ 0 & \text { otherwise }\end{cases}
$$

This variable takes the value 1 if the $i$-th company was EMAS registered on October 25, 2005 and we assume that for these companies the discounted benefits outweigh the discounted costs whereas the opposite holds for all other companies for whom the EMAS variable equals 0 . To examine which characteristics are important, we use a binary response model and estimate

$$
P[E M A S=1]=\Lambda(\beta x)
$$

\footnotetext{
7 A quick scan of the websites of the EMAS registered companies in our sample reveals that the overwhelming majority also has subsidiaries that are certified according to ISO 14001.
} 
where $\Lambda$ is either the cumulative logistic function (logit model) or normal distribution function (probit model), $\beta$ is a vector of parameters to be estimated and $x$ are the characteristics of the firm influencing the costs and benefits of EMAS and hence, the decision to implement it.

\section{Determinants of Environmentally Responsive Companies}

In this section we outline our main hypotheses and define the related independent variables. The European scope of the sample limits the independent variables we were able to include and thus the hypotheses to be tested. Next to Amadeus, the availability of comparable company-level data in Europe is limited. Moreover, the almost non-existence of comparable firm-level environmental performance data in Europe hinders testing whether EMAS participants prove superior environmental performance.

We found inspiration for the majority of our independent variables in the literature. We used averages over a 7-year period (1998-2004) to measure most of the variables. Over 90\% of all EMAS registered companies implemented EMAS in this period. A 7-year average was not relevant for the sector and country dummies and not available for the number of shareholders and subsidiaries. For these variables we used data of 2004. In a perfect world one would take the data from year(s) preceding a company's registration to EMAS. However, this might also create a bias as the implementation time differs considerably between companies. Based on 140 EMAS sites in 12 Member States, Hillary (1998) found it takes some companies over two years while others get registered within 6 months. Moreover one would need to make artificial choices about the year(s) to select for the variables of companies that have not (yet) implemented EMAS. Finally, 7-year averages might help to control for business cycle fluctuations that could influence some variables.

\subsection{Business Characteristics}

Companies with a high number of facilities will face more difficulties in coordinating and monitoring all individual plants. As such, the number of subsidiaries might be a determinant of the need for standardisation of a company's environmental policy and operating procedures. An EMS serves as an instrument to structure the inflow of information and to monitor the implementation of the corporation's policy. A higher number of subsidiaries also serves as a proxy for the visibility of the company. Finally, companies with a larger number of facilities have a greater likelihood of participation since a company was considered a participant if at least one of its facilities volunteered to join. The variable (SUBSIDIARIES) measures the number of subsidiaries in 2004. The number of subsidiaries was previously examined by Arora and Cason (1996) and Dasgupta et al. (2000).

It is commonly hypothesised that the size of a company positively influences the participation decision. Possible explanations include the following. First, larger companies are more visible and face greater scrutiny from various stakeholders (Henriques and Sadorsky 1996; Videras and Alberini 2000; Cole et al. 2006). However, since all the firms in this analysis are publicly quoted and face scrutiny in the financial press, this reason might not be as important in our analysis. Second, the key role of management is to ensure coordination of all actions of the many individuals and subgroups in the organisation. Larger companies face higher coordination costs, as there are more people and activities to coordinate. As such, the need for formal structures and procedures to ensure that all employees are focussing their efforts towards the goals set by the management rises (Henriques and Sadorsky 1996). An EMS might serve as an instrument to reduce these coordination costs. Third, large companies 
presumably have more financial and intellectual resources and experience with management standards like ISO 9001 (Nakamura et al. 2001; Hibiki et al. 2003; Cole et al. 2006). Here, we measure company size in two different ways. First, we use the average number of employees in the period 1998-2004 (EMPLOYEES). Second, we also created an additional size-variable (RELATIVE SIZE) that grasps the relative size of a company compared to the sector average. To do this, we divided the number of employees of a specific company by the average number of employees in all companies in the same 4 digit NACE category in the sample. As such, this variable compares the size of the company to that of its sector-competitors.

Next, we hypothesise that the higher the average labour costs of a company, the more likely it is to have implemented EMAS. Higher average labour costs might represent a higher educated workforce or might refer to rather unsafe working conditions (e.g. higher wages in the nuclear or chemical sector). In the latter explanation, it is obvious that these employees have higher incentives to exert pressure on top management for safe working conditions and pollution abatement efforts. The proposition that a higher educated workforce values sound environmental practices might relate to the fact that higher educated people have a higher environmental awareness and are more capable to exert pressure on top management. Moreover, a highly skilled workforce will make it easier to implement a complex management system as they are generally more trainable, adaptable, and less resistant to change. We took the average costs of employees and averaged it over the years 1998-2004. We will denote this variable with LABOUR COST.

A measure for capital intensity was included under the premise that capital-intensive companies have more complex production technologies; require more energy and raw materials input and hence have higher emission levels (Cole et al. 2006). This induces the need for mechanisms to control these complex and highly polluting processes and in turn provides greater opportunities and scope for the introduction of clean technologies. The variable (CAPITAL INTENSITY) is measured by the ratio fixed assets per employee. Again the average over the years 1998-2004 is taken.

Finally, industry sector dummies are included to take into account industry-specific characteristics (e.g. Henriques and Sadorsky 1996; Videras and Alberini 2000; Hibiki et al. 2003). As such, industry-wide differences with respect to, for instance, pollution intensity, regulatory burden and public concern are controlled for. Also, it controls for the differences with respect to the possibility to implement EMAS. As already noted, some firms were only able to implement it after the revision in 2001. A company's activity was grouped based on the NACE classification Revision 1.1 and grouped into five industry dummies (SECTOR) shown in Table 1. Most companies are found in sector A (mining and quarrying; manufacturing and construction) and $\mathrm{C}$ (wholesale and retail trade, repair of motor vehicles, motorcycles and household goods; hotels and restaurants; transport, storage and communication). Regarding EMAS registered companies, most are situated in sector A. However, in relative terms, sector B (electricity, gas and water supply) has the highest proportion of registered companies. Sectors C, D (financial intermediation; real estate, renting and business activities) and $\mathrm{E}$ (other community, social and personal service activities) count a lower absolute number of EMAS registered companies. In our empirical test, the mining and quarrying, manufacturing and construction sector (sector A) is the omitted dummy. In the sensitivity analysis at the end of Sect. 4 , we present some analysis on the influence of the sector dummy specification on our results.

\subsection{Financial Characteristics}

Implementing an EMS can be considered as a voluntary investment in an intangible asset, which is more likely to occur in companies with a sound financial structure 
Table 1 Sector dummies

\begin{tabular}{|c|c|c|c|c|}
\hline Dummy & NACE & Description & $\begin{array}{l}\text { Number of } \\
\text { companies }\end{array}$ & EMAS \\
\hline \multirow[t]{3}{*}{ Sector A } & $\mathrm{C}$ & Mining and quarrying & 16 & 2 \\
\hline & $\mathrm{D}$ & Manufacturing & 160 & 21 \\
\hline & $\mathrm{F}$ & Construction & 32 & 0 \\
\hline Sector B & $\mathrm{E}$ & $\begin{array}{l}\text { Electricity, gas and water } \\
\text { supply }\end{array}$ & 25 & 10 \\
\hline \multirow[t]{3}{*}{ Sector C } & G & $\begin{array}{l}\text { Wholesale and retail trade; } \\
\text { repair of motor vehicles, } \\
\text { motorcycles and personal and } \\
\text { household goods }\end{array}$ & 51 & 0 \\
\hline & $\mathrm{H}$ & Hotels and restaurants & 13 & 1 \\
\hline & $\mathrm{I}$ & $\begin{array}{l}\text { Transport, storage and } \\
\text { communication }\end{array}$ & 50 & 1 \\
\hline \multirow[t]{2}{*}{ Sector D } & $\mathrm{J}$ & Financial intermediation & 15 & 0 \\
\hline & $\mathrm{K}$ & $\begin{array}{l}\text { Real estate, renting and } \\
\text { business activities }\end{array}$ & 56 & 2 \\
\hline Sector E & $\mathrm{O}$ & $\begin{array}{l}\text { Other community, social and } \\
\text { personal service activities }\end{array}$ & 18 & 1 \\
\hline
\end{tabular}

Note: For the other NACE classes there were no companies in the sample

(Videras and Alberini 2000). It should be noted that the primal objective of an EMS is not to increase short-term profits. In fact, the opposite might be the case. The costs are immediate but the benefits might only materialise in the long run.

First, we include the profit margin as a measure for a company's profitability. More profitable companies are supposed to have easy access to funds, by retained profits or capital markets (Nakamura et al. 2001). The variable (PROFITABILITY) is measured by the average profit margin, defined as profit before taxation on turnover, over the period 1998-2004. Second, we include the solvency ratio (SOLVENCY) and expect a positive sign. The solvency ratio is calculated as shareholders funds on total assets and we use averages over 1998-2004.

\subsection{Stakeholders and Public Policy}

Within the wide range of stakeholders, shareholders and creditors may be important groups requesting the company to adopt a certified EMS. Both may require an EMS as a guarantee of good management in general and environmental risk minimization in particular to safeguard their invested funds. We hypothesize that the higher the number of shareholders the more pressure they will exert. Small shareholders have less influence on and knowledge about the company's operations and strategy compared to major shareholders. As a result, they have more interest in external verification of good management to minimize the risk of future environmental liability. The variable (SHAREHOLDERS) reports the number of shareholders in 2004. A shareholder is reported if he holds at least $1 \%$ of the shares.

The pressure that emanates from creditors is measured by the average of the ratio of noncurrent liabilities on total liabilities over the period 1998-2004 (NON-CURRENT LIABILITIES). The variable only reflects the interests of long-term creditors as we believe short-term creditors do not have an incentive to push the company's policy towards immediate costs for long-term objectives.

Finally, we include the country in which the company's headquarters is located. EMAS participation rates differ significantly form country to country. The national institutional 
Table 2 Descriptive data on country breakdown

\begin{tabular}{lcllr}
\hline Country & $\begin{array}{l}\text { Companies in } \\
\text { the sample }\end{array}$ & $\begin{array}{l}\text { EMAS companies } \\
\text { in the sample }\end{array}$ & $\begin{array}{l}\% \text { EMAS } \\
\text { companies }\end{array}$ & $\begin{array}{l}\text { Support } \\
\text { measures }\end{array}$ \\
\hline UK & 210 & 10 & 4.76 & 6 \\
Germany & 43 & 10 & 23.26 & 17 \\
Netherlands & 34 & 1 & 2.94 & 6 \\
Spain & 34 & 6 & 17.65 & 13 \\
Italy & 24 & 3 & 12.50 & 15 \\
France & 24 & 0 & 0 & 4 \\
Finland & 16 & 5 & 31.25 & 4 \\
Belgium & 14 & 1 & 7.14 & 8 \\
Sweden & 10 & 0 & 0 & 2 \\
Denmark & 6 & 0 & 0 & 8 \\
Switzerland & 6 & 1 & 16.67 & 2 \\
Ireland & 5 & 0 & 0 & 12 \\
Austria & 4 & 1 & 25 & 7 \\
Norway & 3 & 0 & 0 & 4 \\
Luxembourg & 3 & 0 & 0 &
\end{tabular}

a As reported by the European Commission (2004)

context and the government's policy in particular is supposed to play a pivotal role in this regard by e.g. facilitating access to information, granting support funds or shaping attractive public procurement guidelines (e.g. Perkins and Neumayer 2004; Delmas 2002; Kollman and Prakash 2002). The variable is created as dummy variable (COUNRTY) that takes the value 1 if a company's headquarters is located in a Member State that actively encourages EMAS registration. The classification is based on the number of incentives (regulatory flexibility, public procurement, support funding and technical assistance/information support measures) for registered organisations provided by each country as reported by the European Commission (2004). For companies in Germany (17 measures), Italy (15), Spain (13) and Austria (12) the variable takes the value 1 . All other countries in the sample have eight or less incentive measures and are considered as less supportive. Table 2 presents descriptive data on the country breakdown of the companies in our sample. Due to the country breakdown of our sample, i.e. the Dow Jones STOXX 600 list, and the data availability in our databases, the country breakdown does not reflect the relative economic size of a country in the EU. It can be seen that about half of our companies' headquarters are located in the UK. From column four and five it appears that the percentage of EMAS companies in our sample is relatively high for the countries that have a higher number of supportive measures as reflected in our country dummy variable.

Table 3 provides descriptive statistics on the variables and suggests that EMAS registered companies have a higher number of subsidiaries, more employees, are big compared to their average sector size and, to a lesser extent, have a higher number of shareholders and a larger share of non-current liabilities compared to non-registered companies. Also, the location of the companies headquarters and sector dummies B, C and D seem to play a distinctive role. Table A1 in Appendix shows that our variables are not too correlated. In the sensitivity analysis, we check whether the results are sensitive for correlations amongst explanatory variables. 
Table 3 Descriptive statistics

\begin{tabular}{|c|c|c|c|c|}
\hline Variable & Unit & Total sample & $\begin{array}{l}\text { EMAS } \\
\text { companies }\end{array}$ & $\begin{array}{l}\text { Non-EMAS } \\
\text { companies }\end{array}$ \\
\hline \multicolumn{5}{|l|}{ Business characteristics } \\
\hline Subsidiaries & Number & $72.99(121.1)$ & $156.05(265.30)$ & $65.06(93.68)$ \\
\hline Employees & Number $* 1,000$ & $25.49(52.12)$ & $63.66(102.68)$ & $21.84(42.91)$ \\
\hline Relative size & Ratio & $1.085(1.06)$ & $1.914(1.46)$ & $1.006(0.98)$ \\
\hline Labour cost & Thousand euro & $44.68(20.67)$ & $51.51(13.41)$ & $44.03(21.13)$ \\
\hline Capital intensity & Million euro & $0.47(1.57)$ & $0.54(0.71)$ & $0.46(1.63)$ \\
\hline \multicolumn{5}{|l|}{ Financial characteristics } \\
\hline Profitability & Percentage & $8.89(10.29)$ & $8.83(8.19)$ & $8.90(10.48)$ \\
\hline Solvency & Percentage & $38.63(17.72)$ & $39.12(11.77)$ & $38.58(18.20)$ \\
\hline \multicolumn{5}{|c|}{ Stakeholders and public policy } \\
\hline Shareholders & Number & $15.70(18.94)$ & $19.42(22.09)$ & $15.35(18.60)$ \\
\hline Non-current liabilities & Percentage & $43.74(20.66)$ & $56.61(15.01)$ & $42.51(20.72)$ \\
\hline Country & Dummy & $0.24(0.43)$ & $0.53(0.51)$ & $0.21(0.41)$ \\
\hline \multicolumn{5}{|l|}{ Sector dummies } \\
\hline Sector A & Dummy & $0.48(0.50)$ & $0.61(0.50)$ & $0.46(0.50)$ \\
\hline Sector B & Dummy & $0.05(0.23)$ & $0.26(0.45)$ & $0.03(0.19)$ \\
\hline Sector C & Dummy & $0.26(0.44)$ & $0.05(0.23)$ & $0.28(0.45)$ \\
\hline Sector D & Dummy & $0.16(0.37)$ & $0.05(0.23)$ & $0.17(0.37)$ \\
\hline Sector E & Dummy & $0.04(0.20)$ & $0.03(0.26)$ & $0.04(0.20)$ \\
\hline
\end{tabular}

Means and standard deviations

\section{Results}

\subsection{Results of the Basic Specification}

The first column of Table 4 presents the parameter estimates for the logit model. The corresponding probability values are presented between parentheses. As a robustness check, the last column shows the probit results. The results of both estimations are in line. In the following we concentrate on the logit model. The goodness of fit measure count $R^{2}$, defined as the percentage correctly classified observations with the estimated equation is $92.43 \%$. Due to the low number of EMAS registered companies in the sample, this is however only slightly above the percentage estimated with a constant probability measured by simply dividing the number of non-certified companies by the total sample number $(91.28 \%)$. The McFadden $R^{2}$ value is 0.34 and as the likelihood ratio statistic equals 87.67 , the null hypothesis that all coefficients are zero is rejected at the $1 \%$ significance level. However, it should be noted that in binary regressand models the goodness of fit is of secondary importance. The sign of the estimated coefficients and their significance is what matters (Gujarati 2003). This especially holds for the research question at hand.

The second column shows (for the logit model) the change in odds ratio due to an increase in the independent variable by one unit. For instance, the coefficient for the variable employees equals 0.0092 . The corresponding odds ratio $\left(\mathrm{e}^{0.0092}\right)$ is 1.0092 . Then we may say that when the independent variable increases one unit, the odds that the dependent equals 1 increase by a factor of 1.0092, when other variables are controlled for. The closer the odds ratio is to 1, the 
Table 4 Estimation results for EMAS participation

\begin{tabular}{|c|c|c|c|c|}
\hline Variable & $\begin{array}{l}\text { Logit } \\
\text { estimation }\end{array}$ & $\begin{array}{l}\text { Percent } \\
\text { increase } \\
\text { in odds }\end{array}$ & $\begin{array}{l}\text { Percent } \\
\text { increase } \\
\text { in probability }\end{array}$ & Probit estimation \\
\hline \multicolumn{5}{|l|}{ Business characteristics } \\
\hline Subsidiaries & $0.0002(0.9005)$ & 0.020 & 0.002 & $0.0003(0.7012)$ \\
\hline Employees & $0.0092(0.0219)^{* *}$ & 0.928 & 0.074 & $0.0042(0.0523)^{*}$ \\
\hline Relative size & $0.4820(0.0032)^{* * *}$ & 61.938 & 4.675 & $0.2467(0.0052)^{* * *}$ \\
\hline Labour cost & $0.0270(0.0108)^{* *}$ & 2.733 & 0.217 & $0.0122(0.0243)^{* *}$ \\
\hline Capital intensity & $-0.0078(0.9734)$ & -0.78 & -0.062 & $-0.0118(0.9155)$ \\
\hline \multicolumn{5}{|l|}{ Financial characteristics } \\
\hline Profitability & $-0.0432(0.0587)^{*}$ & -4.224 & -0.337 & $-0.0193(0.0920)^{*}$ \\
\hline Solvency & $0.0376(0.0228)^{* *}$ & 3.830 & 0.304 & $0.0175(0.0353)^{* *}$ \\
\hline \multicolumn{5}{|c|}{ Stakeholders and public policy } \\
\hline Shareholders & $0.0062(0.4339)$ & 0.626 & 0.050 & $0.0033(0.4426)$ \\
\hline Non-current liabilities & $0.0341(0.0107)^{* *}$ & 3.469 & 0.275 & $0.0157(0.0162)^{* *}$ \\
\hline Country & $0.7267(0.0990)^{*}$ & 106.829 & 7.775 & $0.4491(0.0531)^{*}$ \\
\hline \multicolumn{5}{|l|}{ Sector dummies } \\
\hline Sector B & $1.6637(0.0048)^{* * *}$ & 427.862 & 24.795 & $0.9469(0.0037)^{\text {*** }}$ \\
\hline Sector C & $-2.6096(0.0066)^{* * *}$ & -92.634 & -8.018 & $-1.0831(0.0068)^{* * *}$ \\
\hline Sector D & $-2.4951(0.0137)^{* *}$ & -91.752 & -7.934 & $-0.9916(0.0255)^{* *}$ \\
\hline Sector E & $-0.4496(0.6826)$ & -36.210 & -2.975 & $-0.2604(0.6342)$ \\
\hline Constant & $-7.4391(0.0000)^{* * *}$ & & & $-3.7660(0.0000)^{* * *}$ \\
\hline$N$ & 436 & & & 436 \\
\hline Log-likelihood & -85.1787 & & & -86.4427 \\
\hline Rest. Log-likelihood & -129.0158 & & & -129.0158 \\
\hline LR statistic (14) & $85.6744^{* * *}$ & & & $85.1463^{* * *}$ \\
\hline Prob. (LR statistic) & $(0.0000)$ & & & $(0.0000)$ \\
\hline$\%$ correctly classified & $92.43 \%$ & & & $92.43 \%$ \\
\hline McFadden $R^{2}$ & 0.3398 & & & 0.3299 \\
\hline
\end{tabular}

$*$, ** and $* * *$ indicate the coefficient is significant at the $10 \%, 5 \%$ and $1 \%$ level respectively

Note: Probability values are shown in parentheses. LR statistic is a chi-square test for all slope coefficients jointly equal to zero

less influence the independent variable exerts on the dependent variable. Equally, one can say that when the variable employees increase by one unit (1,000 employees) the odds of being EMAS registered increase by $0.92 \%$. The third column shows the percent increase in the probability of being certified for a one-unit increase in the independent variable, controlling for the other variables in the model.

Next, we turn to the significance of the estimated coefficients. The estimated coefficients of the number of subsidiaries, the capital intensity, number of shareholders and the sector dummy $\mathrm{E}$ are not significant. The insignificance of the number of subsidiaries corresponds with Arora and Cason (1996) but contradicts with Dasgupta et al. (2000) who found that being a multi-plant company was the most influential variable. Whereas the theoretical arguments for the capital intensity variable were appealing, our unexpected result is also found by 
Cole et al. (2006). In their paper, it even turned out significantly negative for some measures of a company's environmental awareness. Note however that three sector dummy variables are significant. These dummies may partly capture differences in capital intensiveness among companies. Compared to the mining and quarrying, manufacturing and construction sector (sector A), companies involved in electricity, gas or water supply (sector B) are more frequently registered. Companies in the services sectors $\mathrm{C}$ (trade, hotels, restaurants, logistics and communication) and $\mathrm{D}$ (financial intermediation, real estate and business activities) participate significantly less frequent in EMAS. Notwithstanding this finding was expected as on average manufacturing companies face higher environmental risks, it should be taken in account that it was only in April 2001 when the renewed EMAS scheme was implemented that companies in the service sector were allowed to participate. Finally, other community, social and personal service activities (sector E) have no significantly different participation rates compared to the mining, quarrying, manufacturing and construction sector.

The estimated coefficient of the size of a company, measured by the number of employees, is significant at the 5\% level. Controlling for the absolute number of employees, the estimated coefficient of the relative size of a company compared to its sector average turns out positive and significant at $1 \%$. When the relative size ratio increases one unit, the odds of being EMAS registered increase by $61.94 \%$, the probability increases by $4.68 \%$. These results confirm the expectation that larger companies are more likely to have implemented EMAS even when controlling for the number of facilities.

Labour cost's influence on the probability of EMAS implementation is positive and highly significant. This implies that companies with a highly skilled workforce or with unsafe working conditions have a higher probability of having implemented EMAS. This corresponds to some extent with Dasgupta et al.'s (2000) finding that companies in which a higher proportion of employees followed postsecondary education, have a significantly more comprehensive EMS.

When looking at the financial variables, it turns out that the estimated coefficient of the profitability measure is significant at the $10 \%$ level, but has a negative coefficient. This is in contrast with our a priori expectations, but consistent with the diverging results of related research. On the one hand, Cole et al. (2006) found a negative influence whereas Hibiki et al. (2003) found it to be positive. In the results of DeCanio and Watkins (1998), Arora and Cason (1995) and Nakamura et al. (2001) profits do not seem to have a significant influence on a company's environmental responsiveness. This leads to conclude that profit levels do not seem to exert a decisive (positive) impact on this issue. A possible explanation for the negative coefficient may be that the need to differentiate from competitors is higher in more competitive markets where profit margins are generally rather moderate.

The estimated coefficient of the solvency ratio is positive and significant. As the second column shows, an increase in the solvency ratio by 1 percentage point increases the odds of being registered by $3.83 \%$. Furthermore, the higher the share of non-current liabilities the higher the probability a company is EMAS registered. Both confirm that a solid financial structure on the long term is favourable for implementing EMAS. The positive sign of non-current liabilities may also point to the pressure exerted from long-term creditors for the company to demonstrate that it minimises its (environmental) risks. While the estimated coefficient of the number of shareholders was positive but not significant, the coefficient of the non-current liabilities was. This seems to suggest that pressure from external stakeholders is especially relevant for those who provide long-term debt. With respect to debt variables, the results reported in the literature are mixed. The debt ratio turns out negative and significant in Nakamura et al. (2001) and Cole et al. (2006) but insignificant in Arora and Cason (1995), DeCanio and Watkins (1998) and Hibiki et al. (2003). Finally, a stimulating government 
policy, as reflected by the country dummy variable, provokes a positive and significant influence. The probability of being registered are $7.78 \%$ higher for companies whose headquarters is located in Germany, Italy, Spain or Austria compared to the other companies in the sample.

\subsection{Sensitivity Analysis ${ }^{8}$}

In order to check the robustness of our findings in the basic specification discussed above, we conducted a number of sensitivity analyses, which also might help us with the interpretation of our basic results. A first problem could be due to multicollinearity between our explanatory variables. Highly correlated variables make it difficult to separate the influence of these variables on the dependent variable. It could, for instance, be argued that large firms are more likely to pay higher wages and are more capital intensive. In order to check for potential biases in our results due to multicollinearity, we estimated the regression several times dropping each individual variable once at a time. The estimation output of this exercise is provided in Appendix (Table A2). This exercise shows that the results found in the basic specification are quite robust. The most notable change concerns the size of the company as measured with employees, which becomes insignificant when the sector dummy variables are dropped. Also, the profitability variable and the country dummy lose their significance in two out of eleven specifications. This is in line with the finding that these variables were only significant at the $10 \%$ level in the basic specification.

Specification 7 and 9 provide some further analysis on the influence of a company's financial structure. Specification 9 excludes the non-current liabilities variable. The coefficient on the solvency variable stays positive and significant. As the debt ratio, defined as the current and non-current liabilities on total assets, equals 1 minus the solvency ratio, this finding also implies that the higher the debt ratio of a company, the less likely the company will seek EMAS registration. The results in our basis analysis as well as those presented in Table A2 show that the composition of the debt matters. In both specifications the coefficient on the non-current liabilities variable is positive and significant. This leads to the conclusion that whereas debt has a negative influence, the share of non-current liabilities in this debt positively influences the probability of participation in EMAS. Consequently, the share of current liabilities exerts a negative influence. This suggests that companies with access to stable long-term debt markets are more inclined to adopt EMAS.

Specification 10 excludes the country dummy variable and can be used to further grasp the influence of the institutional context. The results with respect to the other variables are confirmed: all variables that were significant, remain significant, the others stay insignificant. Only the significance level of the non-current liabilities variable changes from $5 \%$ to $1 \%$. The determinants of company participation in EMAS do not respond to differences in the institutional context. The same conclusion stems from Sect. 4.1 where we discussed our results with respect to related literature on US and Japanese companies. Nevertheless, studies like Delmas (2002) and Kollman and Prakash (2002) have pointed to the explanatory value for grasping international cross-country differences in ISO 14001 uptake. Corresponding results were found by Perkins and Neumayer (2004) in explaining the geography of EMAS in the European Union. These seemingly contradicting findings might point to the fact that whereas the institutional context has little influence on the kind of companies that participate in these voluntary schemes, it influences the amount of these companies that participate. Rather than attracting other kinds of companies, a fertile formal and informal environment succeeds in

8 The authors would like to thank an anonymous referee for numerous suggestions with respect to these sensitivity tests. 
attracting more of the same group of companies. It gets more companies out of the target group rather than enlarging the target group.

The second sensitivity analysis further focuses on the influence of the country dummy variable. The basic specification revealed that the country dummy variable was significant at the $10 \%$ level. Some additional analysis, shown in Appendix (Table A3), points out that this result is not robust. First, specification 1 only includes those companies that are situated in a country that has at least one EMAS registered company. This limits the sample to 385 companies. The country dummy variable is no longer significant in this specification. In the second specification, we included separate dummy variables for the countries that are indicated as supportive based on the number of supportive measures initiated by the government. In this case, we reset the sample at its basic level of 436 companies. The results show that whereas the coefficients of the country dummies have the expected positive sign, only companies whose headquarters is located in Spain have a significantly higher probability of EMAS registration compared to companies located in the less supportive countries. To conclude, the significance of the country dummy variable might be driven by Spain.

The third sensitivity analysis focuses on the influence of the sector dummies on the estimation results. The results are presented in Appendix (Table A4). As a first exercise, we excluded sector B. Sector B includes the electricity, gas and water supply companies. This sector is highly capital intensive and has a monopolistic sector. Besides, these companies are highly profitable and likely to be under government and public pressure. The rather high proportion of EMAS registered companies can be explained in this regard and this is likely to skew the results. The results of the first specification where firms in sector B are dropped from the analysis, confirm our basic findings. The variable on profitability and the country dummy are no longer significant, but the other conclusions hold. In the second specification, we additionally dropped firms from sectors C, D and E because of the low amount of EMAS registered companies in these sectors. Again, the profitability variable and the country dummy loose their significance. In the last specification, we further limited the sample to a subset firms within sector A. More specifically we only included the manufacturing sector. This subsector is rather competitive and counts a relatively high amount of EMAS as well as non-EMAS registered companies. Besides, until 2001 EMAS was only open for companies in the manufacturing sector. With the exception of relative size that is no longer significant, the basic results are unaffected. Note however that in this case the sample is restricted to only 160 companies.

As a final sensitivity analysis we estimated the regression with some alternative variable specifications. The results are shown in Appendix (Table A5). The second column shows the result of our basic specification and is included as a benchmark for comparison. In the second specification, we measured the absolute and relative size of a company based on turnover. The corresponding coefficients are positive and significant at the $1 \%$ respectively $10 \%$ level. In specification 3, we define the variable capital intensity as total assets per employee instead of fixed assets per employee. This does not substantially alter the results of the basic specification. When the return on total assets is used as an alternative measure for profitability of a company instead of the profit margin (specification 4), the estimated coefficient also turn out negative but insignificant. This result again shows that the conclusion on the negative influence of the profitability on EMAS registration is not that robust. The same picture stems from specification 5 in which the four alternative variable specifications discussed above are included. Finally, we point to the fact that the country dummy variable is not significant in any of the alternative specifications.

All in all, our sensitivity analyses clearly suggest that the results obtained in the basic specification are quite robust. Across various specifications that we have tested, both the 
significance as well as the sign of most variables is unaffected compared to the basic results. The same holds for alternative ways to calculate a number of our variables.

\section{Conclusions}

Responding proactively to growing environmental pressure is becoming a widespread trend among companies. It goes without saying that the level of commitment however is uneven ranging from environmental leaders to defensive companies. Empirical research on the characteristics of environmentally responsive companies has focussed almost exclusively on US and Japanese firms. For Europe, which is commonly considered as the greenest of the three major developed economic markets, similar research is lacking. This paper seeks to contribute by empirically investigating the business and financial characteristics, stakeholder pressure and public policies distinguishing companies that have implemented EMAS. A logistic regression analysis was carried out on a sample of 436 European companies listed on the Dow Jones Stoxx 600 selection list. Our results indicate that large companies with a sound financial structure and high average labour costs have a higher likelihood of participating in EMAS. Also the relative size of a company compared to its sector average increases the likelihood of participation. The profitability on the other hand exerts a negative influence. Also, the location of a company's headquarters, which should capture differences in the institutional context, and the industrial sector determine the likelihood of EMAS participation. However, the exclusion of the country variable did not influence the determinants of EMAS participants.

Both the fact that EMAS has a closer relationship with public regulators compared to private initiatives like ISO 14001 and Responsible care as well as diverging formal and informal institutions in the European Union compared to US and Japan suggested that the results might differ from previous studies on the characteristics of environmental leading companies. Overall however, our conclusions are in line with related findings from research carried out in the US and Japan. Although evidence is still limited, this might point to a rather moderate influence of the institutional context when it comes to distinguishing the characteristics of environmentally leading companies. The literature on the geographical diffusion of EMS on the other hand points to the decisive role of institutional-related aspects to explain the diverging adoption rates between countries. We believe these seemingly contradicting results can be reconciled. Rather than attracting companies with other characteristics, a favourable institutional context seems to be able to convince more companies from the target group. Linking these two findings further might be a challenging task for future research.

Another issue that calls for further exploration is the question whether the adoption of voluntary initiatives makes companies outperform others on environmental abatement. Clear signals of added value above business-as-usual assessments are required to justify that many voluntary initiatives provide benefits for participants in the form of decreased regulatory pressure, subsidies or positive publicity. Increasing the amount of and reliability of environmental information is crucial to enhance transparency and enable public monitoring efforts. The Toxic Release Inventory in the US is a forerunner in this regard en has enabled this kind of research. For now, the findings do not permit an incontestable answer. Unfortunately, comparable firm level environmental performance data is lacking in Europe. A database on firm level $\mathrm{CO}_{2}$-emissions created in the wake of the recent emission-trading directive on greenhouse gas emissions might provide us with a promising indicator in this regard. 


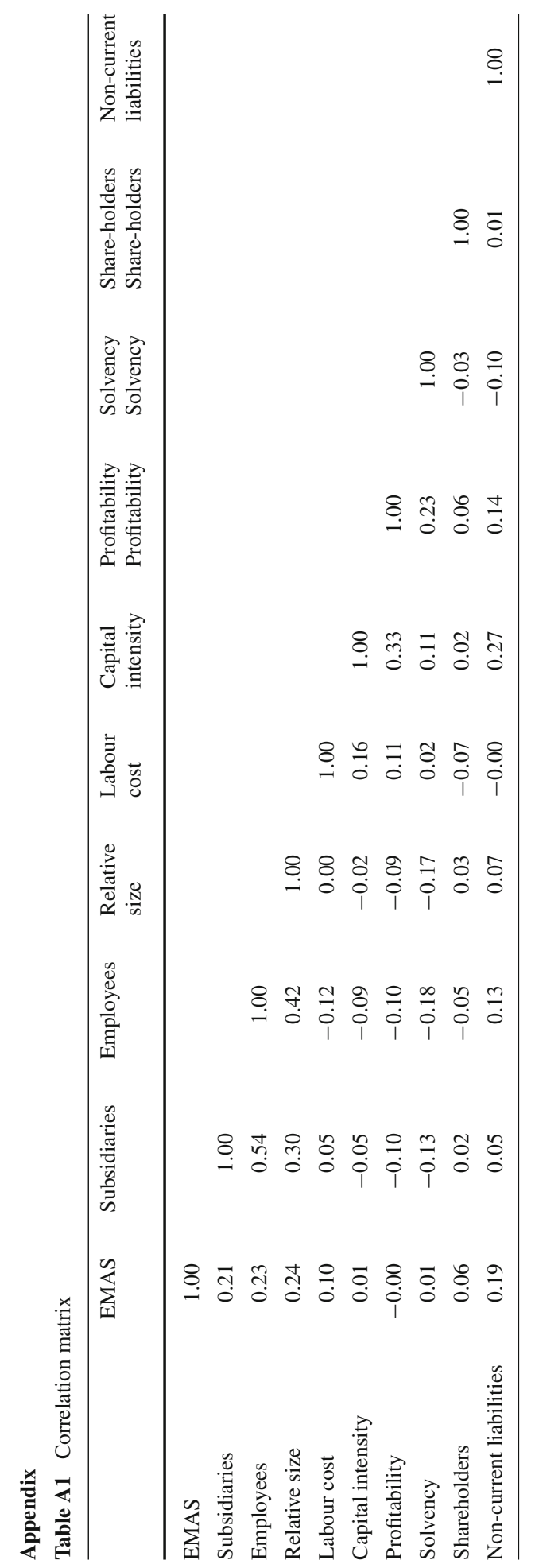




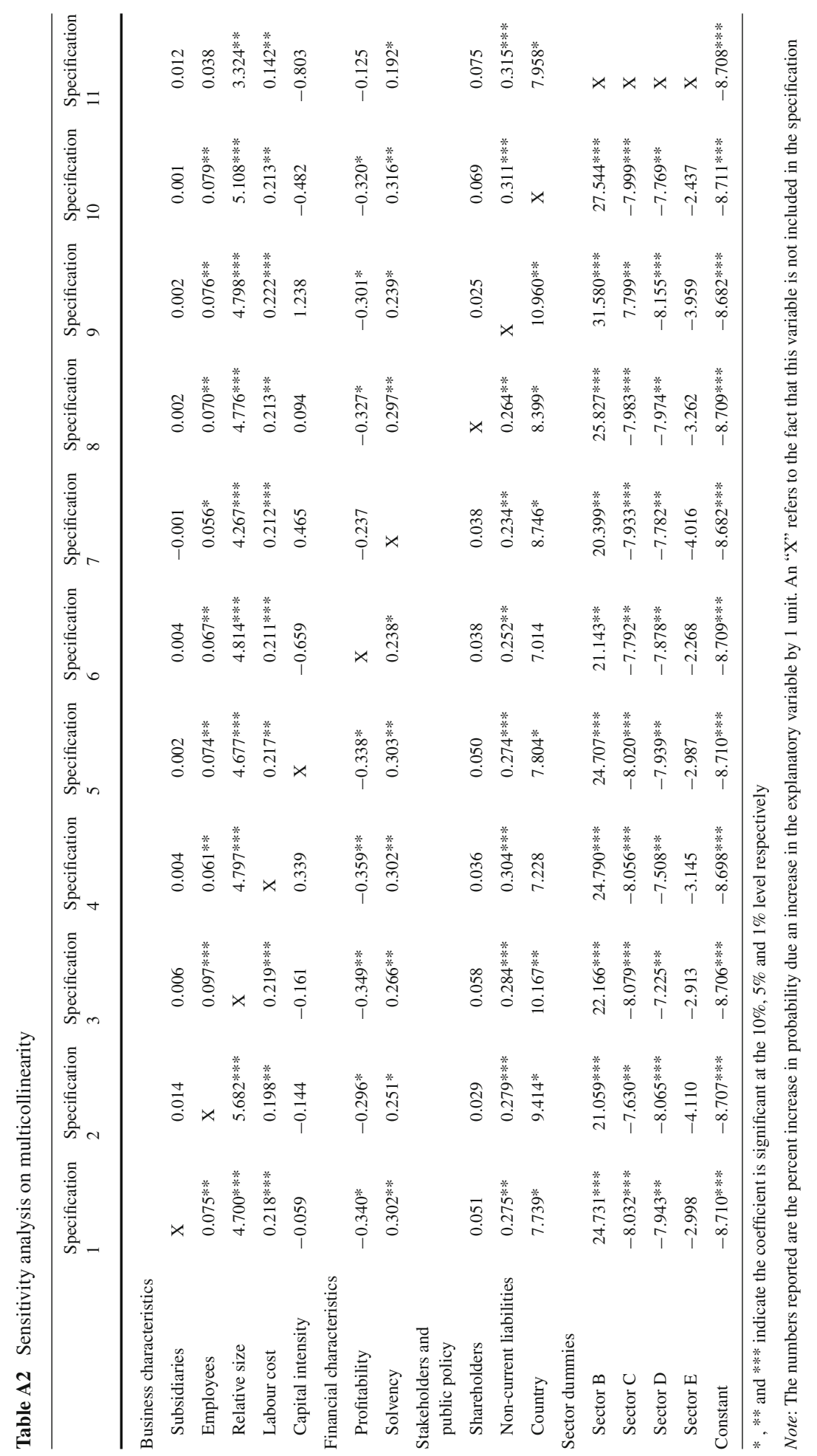


Table A3 Sensitivity analysis on the country dummy variable

\begin{tabular}{|c|c|c|}
\hline & $\begin{array}{l}\text { Specifcation } \\
1(N=385)\end{array}$ & $\begin{array}{l}\text { Specification } \\
2(N=436)\end{array}$ \\
\hline \multicolumn{3}{|l|}{ Business characteristics } \\
\hline Subsidiaries & 0.003 & 0.000 \\
\hline Employees & $0.069 * *$ & $0.083 * *$ \\
\hline Relative size & $5.408 * * *$ & $4.794 * * *$ \\
\hline Labour cost & $0.241 * * *$ & $-0.229 * * *$ \\
\hline Capital intensity & 0.497 & -0.425 \\
\hline \multicolumn{3}{|l|}{ Financial characteristics } \\
\hline Profitability & $-0.334 *$ & $-0.364 * *$ \\
\hline Solvency & $0.285^{* *}$ & $0.317 * *$ \\
\hline \multicolumn{3}{|c|}{ Stakeholders and public policy } \\
\hline Shareholders & 0.042 & 0.010 \\
\hline Non-current liabilities & $0.256 * *$ & $0.322 * *$ \\
\hline Country & 5.850 & $\mathrm{X}$ \\
\hline Austria & & 15.810 \\
\hline Germany & & 2.749 \\
\hline Italy & & 6.799 \\
\hline Spain & & $22.985^{*}$ \\
\hline \multicolumn{3}{|l|}{ Sector dummies } \\
\hline Sector B & $21.884 * *$ & $20.796^{* *}$ \\
\hline Sector C & $-8.048 * * *$ & $-8.132 * * *$ \\
\hline Sector D & $-8.185 * * *$ & $-7.916^{* *}$ \\
\hline Sector E & -2.568 & -3.471 \\
\hline Constant & $-8.709 * * *$ & $-8.711 * * *$ \\
\hline
\end{tabular}

$*$, ** and *** indicate the coefficient is significant at the $10 \%, 5 \%$ and $1 \%$ level respectively

Note: The numbers reported are the percent increase in probability due an increase in the explanatory variable by 1 unit. An " $\mathrm{X}$ " refers to the fact that this variable is not included in the specification

Table A4 Sensitivity analysis on the sector dummies

\begin{tabular}{lccc}
\hline & $\begin{array}{l}\text { Sample excl. sector } \\
\mathrm{B}(N=411)\end{array}$ & $\begin{array}{l}\text { Sector A } \\
(N=208)\end{array}$ & $\begin{array}{l}\text { Manufacturing } \\
(N=160)\end{array}$ \\
\hline $\begin{array}{l}\text { Business characteristics } \\
\text { Subsidiaries }\end{array}$ & 0.007 & 0.000 & -0.002 \\
Employees & $0.074 * *$ & $0.126 * * *$ & $0.154 * * *$ \\
Relative size & $4.782^{* * *}$ & $7.468^{* * *}$ & 5.792 \\
Labour cost & $0.202 * *$ & $0.548^{* * *}$ & $0.682 * * *$ \\
Capital intensity & -0.209 & -5.743 & -4.442 \\
Financial characteristics & & & 0.065 \\
Profitability & -0.244 & -0.167 & $0.438 *$ \\
Solvency & $0.395^{* * *}$ & $0.487 * *$ & \\
\hline
\end{tabular}


Table A4 continued

\begin{tabular}{lccc}
\hline & $\begin{array}{l}\text { Sample excl. sector } \\
\mathrm{B}(N=411)\end{array}$ & $\begin{array}{l}\text { Sector A } \\
(N=208)\end{array}$ & $\begin{array}{l}\text { Manufacturing } \\
(N=160)\end{array}$ \\
\hline $\begin{array}{l}\text { Stakeholders and public policy } \\
\text { Shareholders }\end{array}$ & 0.063 & 0.123 & 0.164 \\
Non-current liabilities & $0.401 * * *$ & $0.696 * * *$ & $0.822^{* * *}$ \\
Country & 5.968 & 0.972 & -2.351 \\
Sector dummies & & & \\
Sector C & $-8.050 * * *$ & & $-8.716^{* * * *}$ \\
Sector D & $-7.915 * *$ & & \\
Sector E & -1.961 & -8.716 & \\
Constant & $-8.714 * * *$ & & \\
\hline
\end{tabular}

$*$, ** and $* * *$ indicate the coefficient is significant at the $10 \%, 5 \%$ and $1 \%$ level respectively

Note: The numbers reported are the percent increase in probability due an increase in the explanatory variable by 1 unit

Table A5 Sensitivity analysis on alternative variable specifications

\begin{tabular}{|c|c|c|c|c|c|}
\hline & $\begin{array}{l}\text { Specification } \\
1\end{array}$ & $\begin{array}{l}\text { Specification } \\
2\end{array}$ & $\begin{array}{l}\text { Specification } \\
3\end{array}$ & $\begin{array}{l}\text { Specification } \\
4\end{array}$ & $\begin{array}{l}\text { Specification } \\
5\end{array}$ \\
\hline \multicolumn{6}{|l|}{ Business characteristics } \\
\hline Subsidiaries & 0.002 & -0.006 & 0.002 & 0.003 & -0.007 \\
\hline Employees & $0.074 * *$ & & $0.076^{* *}$ & $0.068 * *$ & \\
\hline Turnover & & $0.001 * * *$ & & & $0.001 * * *$ \\
\hline Relative size & $4.675^{* * * *}$ & & $4.496 * * *$ & $4.791 * * *$ & \\
\hline Relative size on turnover & & $3.340 *$ & & & $3.281 *$ \\
\hline Labour cost & $0.217 * *$ & 0.117 & $0.241 * * *$ & $0.216 * * *$ & $0.159 *$ \\
\hline Capital intensity & -0.062 & -1.484 & & -0.746 & \\
\hline Total assets per employee & & & -0.672 & & -0.252 \\
\hline \multicolumn{6}{|l|}{ Financial characteristics } \\
\hline Profitability & $-0.337 *$ & $-0.333^{*}$ & $-0.343^{*}$ & & \\
\hline Return on total assets & & & & -0.124 & -0.326 \\
\hline Solvency & $0.304 * *$ & $0.345^{* *}$ & $0.328 * *$ & $0.251 *$ & $0.339 * *$ \\
\hline \multicolumn{6}{|l|}{ Stakeholders and public policy } \\
\hline Shareholders & 0.050 & 0.0328 & 0.054 & 0.038 & 0.029 \\
\hline Non-current liabilities & $0.275^{* *}$ & $0.300 * * *$ & $0.284 * * *$ & $0.246^{* *}$ & $0.264 * *$ \\
\hline Country & $7.775^{*}$ & 6.306 & 7.399 & 7.255 & 5.792 \\
\hline \multicolumn{6}{|l|}{ Sector dummies } \\
\hline Sector B & $24.795 * * *$ & $30.121 * * *$ & $26.180 * * *$ & $20.619 * *$ & $27.046 * * *$ \\
\hline Sector C & $-8.018^{* * * *}$ & $-8.057 * * *$ & $-8.041 * * *$ & $-7.849 * *$ & $-7.933 * * *$ \\
\hline Sector D & $-7.934 * *$ & $-6.969 *$ & $-7.798 * *$ & $-7.893 * *$ & $-6.703^{*}$ \\
\hline Sector E & -2.975 & -1.255 & -2.838 & -2.385 & -0.201 \\
\hline Constant & $-8.710 * * *$ & $-8.709 * * *$ & $-8.711 * * *$ & $-8.708 * * *$ & $-8.708 * * *$ \\
\hline
\end{tabular}

$*, * *$ and $* * *$ indicate the coefficient is significant at the $10 \%, 5 \%$ and $1 \%$ level respectively

Note: The numbers reported are the percent increase in probability due an increase in the explanatory variable by 1 unit 


\section{References}

Alberini A, Segerson K (2002) Assessing voluntary programs to improve environmental quality. Environ Resour Econ 22(2):157-184

Anton W, Deltas G, Khanna M (2004) Incentives for environmental self-regulation and implications for environmental performance. J Environ Econ Manage 48:632-654

Arora S, Cason T (1995) An experiment in voluntary environmental regulation: participation in EPA's 33/50 program. J Environ Econ Manage 28:271-286

Arora S, Cason T (1996) Why do firms volunteer to exceed environmental regulations? Understanding participation in EPA's 33/50 Program. Land Econ 72(4):413-432

Clausen J, Keil M, Jungwirth M (2002) The state of EMAS in the EU: literature survey. http://ec.europe.eu/ environment/emas/pdf/general/literture_survey_020506_en.pdf

Cole M, Elliott R, Shimamoto K (2006) Globalization, firm-level characteristics and environmental management: a study of Japan. Ecol Econ 59:312-323

Dasgupta S, Hettige H, Wheeler D (2000) What improves environmental compliance? Evidence from Mexican industry. J Environ Econ Manage 39:39-66

DeCanio S, Watkins W (1998) Investment in energy efficiency: do the characteristics of firms matter? Rev Econ Statist 80(1):95-107

Delmas M (2002) The diffusion of environmental management standards in Europe and in the United States: an institutional perspective. Policy Sci 35:91-119

Delmas M, Terlaak A (2002) Regulatroy commitment to negotiated agreements: evidence from the United States, Germany, The Netherlands and France. J Comp Policy Anal Res Pract 4:5-29

EC (2004) Annex to the report from the Commission to the Council and the European Parliament on incentives for EMAS registered organisations. COM(2004)745 Final, Brussels

Fairtrade Labelling Organization International (2006) Building trust: annual report 2005

Gujarati D (2003) Basic econometrics. McGraw-Hill Higher Education

Henriques I, Sadorsky P (1996) The determinants of an environmentally responsive firm: an empirical approach. J Environ Econ Manage 30:381-395

Hibiki A, Higashi M, Matsuda A (2003) Determinants of firms to acquire ISO 14001 certificate and market valuation of the certified firm. Discussion paper no. 03-06, National Institute for Environmental Studies

Hillary R (1998) Pan European Union assessment of EMAS implementation. Eur Environ 8:184-192

Honkasalo A (1998) The EMAS scheme: a management tool and instrument of environmental policy. J Cleaner Prod 6:119-128

International Organization for Standardization (2006) The ISO survey of certifications 2005. Geneva

Khanna M, Anton R (2002) Corporate environmental management: regulatory and market-based incentives. Land Econ 78(4):539-558

Khanna M, Damon L (1999) EPA's voluntary 33/50 program: impact on toxic releases and economic performance of firms. J Environ Econ Manage 37:1-25

King A, Lenox M (2000) Industry self-regulation without sanctions: the chemical industry's responsible care program. Acad Manage J 43(6):698-716

Kollman K, Prakash A (2002) EMS-based environmental regimes as club goods: examining variations in firm-level adoption of ISO 14001 and EMAS in U.K., U.S. and Germany. Policy Sci 35:43-67

Nakamura M, Takahashi T, Vertinsky I (2001) Why Japanese firms choose to certify: a study of managerial responses to environmental issues. J Environ Econ Manage 42:23-52

OECD (1999) Voluntary approaches for environmental policy—an assessment. Paris

Perkins R, Neumayer E (2004) Europeanization and the uneven convergence of environmental policy: explaining the geography of EMAS. Environ Plan C Gov Policy 22(6):881-897

Potoski M, Prakash A (2005) Green clubs and voluntary governance: ISO 14001 and firms' regulatory compliance. Am J Pol Sci 49(2):235-248

Steger U (2000) Environemntal management systems: empirical evidence and further perspectives. Eur Manage $\mathrm{J}$ 18:23-37

Videras J, Alberini A (2000) The appeal of voluntary environmental programs: which firms participate and why?. Contemp Econ Policy 18(4):449-461

Vogel D (1986) National styles of regulation: environmental policy in Great Britain and the United States. Cornell University Press, London

Watson M, Emery A (2004) Law, economics and the environment: a comparative study of environmental management systems. Manage Audit J 19(6):760-773

Welch E, Hibiki A (2002) Japanese voluntary environmental agreements: bargaining power and reciprocity as contributors to effectiveness. Policy Sci 35:401-424 